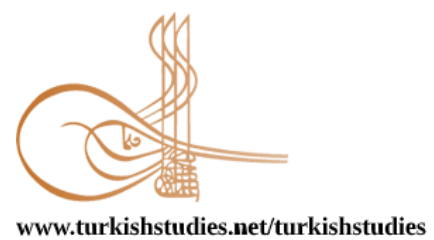

Turkish Studies

\title{
Covid-19 Salgınının ve Karantinanın Psikolojik Etkileri
}

\author{
Psychological Effects of Covid-19 Epidemic and Quarantine
}

\author{
İrem Öztürk ${ }^{*}$ - Seda Akalın ${ }^{* *}$ - İrem Özgüner ${ }^{* * *}$ - Mehmet Şakiroğlu ${ }^{* * * *}$
}

\begin{abstract}
This study aims to investigate the psychological effects of the epidemic outbreak and quarantine in individuals aged 18-65. 357 individual, 251 women $(70.3 \%)$ and 106 men $(29.7 \%)$, participated in the study. Participants were given online on the sociodemographic information form, questions about pet ownership and plant ownership, telephone use, Intolerence of Uncertainty Scale, Leisure Boredom Scale, and Impact of Events Scale. In the analysis of the data; bivariate correlation, independent samples $t$-test and linear regression analysis were used. Individuals who do not have pets have higher scores from Impact of Events Scale and Intolerence of Uncertainty Scale than who have pets. No difference was found between the scale scores of individuals with and without plants. According to the correlation analysis, there is a significant and positive relationship between all scales. According to the standardized regression coefficients of linear regression; the order of importance of the predictive variables on the effects of events was determined as intolerance of uncertainty, leisure boredom, home environment, time spent on the phone, socioeconomic level and use of twitter. The world is struggling with a pandemic outbreak. Results indicate that having a pet, living in a detached house, high socioeconomic level may be a protective factor and high levels of intolerance of uncertainty, leisure boredom, time spent on the phone and use of twitter may be a risk factor. It is recommended to increase the number of studies using these variables.
\end{abstract}

Structured Abstract: In this study, the level of covid-19 epidemic and quarantine affecting people was investigated and psychological variables that increase or decrease this level were investigated. The main

\footnotetext{
* Psikolog, Aydın Adnan Menderes Üniversitesi, Sağlık Bilimleri Enstitüsü, Klinik Psikoloji Bölümü Psychologist, Aydin Adnan Menderes University, Institute of Health Sciences, Department of Clinical Psychology ORCID 0000-0003-0427-5784 pskiremozturkk@gmail.com

** Psikolog, Aydın Adnan Menderes Üniversitesi, Sosyal Bilimler Enstitüsü, Aile Danışmanlığı Bölümü Psychologist, Aydin Adnan Menderes University, Institute of Social Sciences, Department of Family Counseling ORCID 0000-0002-1278-2017

akalinseda48@gmail.com

${ }^{* * * *}$ Psikolog, Aydın Adnan Menderes Üniversitesi, Sağlık Bilimleri Enstitüsü, Klinik Psikoloji Bölümü Psychologist, Aydin Adnan Menderes University, Institute of Health Sciences, Department of Clinical Psychology ORCID 0000-0002-9364-618X irem_ozguner@hotmail.com
}

***** Dr. Öğr.Üyesi, Aydın Adnan Menderes Üniversitesi, Fen Edebiyat Fakültesi, Psikoloji Bölümü Assist Prof. Dr., Aydin Adnan Menderes University, Faculty of Letters, Department of Psychology ORCID 0000-0001-8990-621X mehmet.sakiroglu@adu.edu.tr Cite as/ Atıf: Öztürk, İ., Akalın, S., Özgüner, İ. \& Şakiroğlu, M. (2020). Covid-19 salgınının ve karantinanın psikolojik etkileri. Turkish Studies, 15(4), 885-903. https://dx.doi.org/10.7827/TurkishStudies.44885

Received/Geliş: 06 July/Temmuz 2020

Accepted/Kabul: 10 August/Ağustos 2020

Copyright (C) MDE, Turkey
Copyight $\mathrm{MDE}$ Turkey 
cause of anxiety when new epidemics occur is that the exact cause of the disease is unknown. At this point, the importance of the concepts of uncertainty and intolerance of uncertainty, which is a predictor of anxiety (etc. Fergus \& Wu, 2011; Khawaja \& McMahon, 2011; Mahoney \& McEvoy, 2012), becomes apparent. Studies focused on the Covid-19 outbreak found that intolerance of uncertainty and psychological health are related to each other (Alizadeh Fard \& Alipour, 2020; Satıc1 etal., 2020). In addition to the uncertainty situation, people's leisure time increases in the quarantine process. The enjoyable activities that can be done in these spare times have also become limited. In Covid-19 quarantine, it was seen that people experience leisure boredom (de Medeiros Carvalho etal., 2020). Staying inside homes and the inability to fill up leisure time during the quarantine period can lead to increased phone usage. It is known that problematic phone and internet usage has negative effects on mental health (etc. Şakiroglu, 2020; Roberts etal., 2015; Yen etal., 2007). Based on the findings in the literature, the variables considered as a risk factor in the Covid-19 epidemic process and aimed to be investigated in the research were determined as intolerance of uncertainty, leisure boredom, and the duration of telephone and social media use.

Psychological factors that can be protective against the difficulties of this process are also very important. The positive effects of being related to nature on human health have been proven by many studies (etc. Cole \& Hall, 2010; Hartig etal, 2003). There is no article investigating the psychological effect of nature in the context of Covid-19. One of the most important aspects in the human-nature relationship is the relationship established with animals. It is known that pets have positive effects on human psychology (etc. Brooks etal., 2018; Jones etal., 2019; Bibbo etal., 2019; Antonacopoulos \& Pychyl, 2010; Garrity vd., 1989). There are studies proposing to investigate the positive effect of the pet on human psychology in the Covid-19 process (Hoy-Gerlach etal. 2020; Vincent etal., 2020). Based on all these studies, the variables considered as a protective factor in the Covid-19 epidemic process and aimed to be investigated in the research were determined as owning plants and pets.

This study aims to contribute to the literature and to bring a new perspective to the Covid-19 pandemic through the variables it examines. In line with the purpose of the study, 5 hypotheses have been established: H1: As the scores obtained from the Intolerance of Uncertainty Scale increase, the scores from the Impact of Event Scale will also increase. H2: As the scores obtained from the Leisure Boredom Scale increase, the scores obtained from the Impact of Event Scale will also increase. H3: As the time spent on the phone increases, the scores obtained from the Scale of the Impact of the Event will also increase. H4: The scores obtained by the individuals who have pets from Intolerence of Uncertainty, Leisure Boredom and Impact of Event Scales will be lower than the scores obtained by individuals who do not have pets. H4: The scores obtained by the individuals who have plants from Intolerence of Uncertainty, Leisure Boredom and Impact of Event Scales will be lower than the scores obtained by individuals who do not have plants.

Method: 357 individual, 251 women (70.3\%) and 106 men (29.7\%), participated in the study. The data were collected through the students of Aydin Adnan Menderes University Psychology and Psychological Counseling and Guidance departments who returned to their hometown during the pandemic. Participants were given online on the sociodemographic information form, questions about pet ownership and plant ownership, telephone use, Intolerence of Uncertainty Scale, Leisure Boredom Scale, and Impact of Events Scale. In the analysis of the data; bivariate correlation, independent samples t-test and linear regression analysis were used.

Findings: Individuals who do not have pets have higher scores from Impact of Events Scale and Intolerence of Uncertainty Scale than who have pets. Boş Zaman Can Sıkıntısı Ölçeği'nden alınan puanlar evcil hayvan sahipleri ve evcil hayvanı olmayan bireyler arasında farklılaşmamıştır. No difference was found between the scale scores of individuals with and without plants. According to the correlation analysis, there is a significant and positive relationship between all scales. According to linear regression; intolerance of uncertainty, leisure boredom, home environment, time spent on the phone, socioeconomic level and the use of Twitter were obtained as variables which predict effects of epidemic and quarantine. Results indicate that having a pet, living in a detached house, high socioeconomic level may be a protective factor and high levels of intolerance of uncertainty, leisure boredom, time spent on the phone and use of twitter may be a risk factor.

Conclusion: Covid-19 pandemic brings some risk factors and protective factors with itself. In the study, having a pet, living in a detached house and having a high socioeconomic level were found as protective factors. It is seen that pets are a source of social support in times of crisis, just as in daily life. A

Turkish Studies 15(4) 
detached house and high income level indicate high socioeconomic status. This finding implies that individuals with low socioeconomic level are at risk. To examine this situation in more depth, studies can be conducted with socioeconomically disadvantaged groups. Risk factors were found as high levels of intolerence of uncertainty and leisure boredom, increased time spent over the phone, and the use of twitter. The Covid-19 outbreak includes many uncertainties. The quarantine process increases the free time considerably. For this reason, it is understandable that individuals with high levels of intolerance of uncertainty and leisure boredom are more affected by the epidemic and quarantine. Increased duration of leisure and limited activities increase the time spent over the phone. In this case, it is possible that the use of the phone will become problematic. Meanwhile, spending time on Twitter increases the negative effect of epidemic and quarantine. This can be explained by the fact that Twitter is a social media application mainly used for following news. Reading news about infected people may increase the level of exposure.

This study is important in terms of investigating not only risk factors but also protective factors. It is suggested to increase the number of studies using these variables for future research. Another suggestion is to conduct face-to-face studies with individuals who do not have internet access later in the normalization process.

Keywords: Psychology, Covid-19 pandemic, Pet, Plant, Intolerence of Uncertainty, Leisure Boredom, Impact of Event

Öz: Bu çalışma, 18-65 yaş arasındaki bireylerde salgının ve karantinanın psikolojik etkilerinin incelenmesini amaçlamaktadır. Çalışmanın katılımcılarını 251'i kadın (\%70.3), 106'sı erkek (\%29.7) 357 kişi oluşturmaktadır. Katılımcılara evcil hayvan ve bitki sahipliği ile telefon kullanımı hakkındaki soruları içeren bilgi formu, Belirsizliğe Tahammülsüzlük Ölçeği, Boş Zaman Can Sıkıntısı Ölçeği ve Olayın Etkisi Ölçeği çevrimiçi olarak verilmiştir. Verilerin analizinde bivariate korelasyon, bağımsız örneklemler için $t$-testi ve linear regresyon analizleri kullanılmıştır. Evcil hayvan sahibi olmayan bireylerin Olayın Etkisi Ölçeği ile Belirsizliğe Tahammülsüzlük Ölçeği’nden aldıkları skorlar, evcil hayvan sahibi olan bireylere göre daha yüksek bulunmuştur. Bitki sahibi olan ve olmayan bireylerin araştırmada kullanılan ölçeklerden aldıkları puanlar arasında herhangi bir farklılaşma bulunmamıştır. Yapılan korelasyon analizine göre bütün ölçekler arasında anlamlı ve pozitif bir ilişki mevcuttur. Linear regresyonun standartlaştırılmış regresyon katsayılarına göre; yordayıcı değişkenlerin olayların etkisi üzerindeki önem sırası belirsizliğe tahammülsüzlük, boş zaman can sıkıntısı, ev ortamı, telefon ile geçirilen süre, sosyoekonomik düzey ve twitter kullanımı olarak saptanmıştır. Bulgular; evcil hayvan sahibi olmanın, yaşanılan ev ortamının, sosyoekonomik düzeyin koruyucu faktör, belirsizliğe tahammülsüzlük ile boş zaman can sıkıntısı düzeylerinin, telefon ile geçirilen sürenin ve twitter kullanımının yüksek olmasının ise risk faktörü olabileceğine işaret etmektedir. Söz konusu değişkenleri kullanan çalışmaların sayısının arttırılması önerilmektedir. Çalışma, Aydın Adnan Menderes Üniversitesi Sosyal ve Beşeri Bilimler Etik Kurulu tarafından (Etik Kurul Onay Kodu: 31906847/050.04.0408/14) onaylanmıştır

Anahtar Kelimeler: Psikoloji, Covid-19 pandemisi, Evcil Hayvan, Bitki, Belirsizliğe Tahammülsüzlük, Boş Zaman Can Sıkıntısı, Olayın Etkisi

\section{Giriş}

Dünyanın Covid-19 salgını ile tanışması 31 Aralık 2019 tarihine denk gelmektedir (WHO, 2020a). Hastalığın çıkış yeri Çin'in Wuhan kentidir. İlk etapta, hastalığın merkez üssü Çin ve çevresi iken, ilerleyen zamanlarda Asya sınırlarını aşarak bütün dünyaya yayılmıştır. 11 Mart 2020 tarihinde söz konusu hastalık, Dünya Sağlık Örgütü (DSÖ) tarafindan "pandemi" olarak nitelendirilmiștir (WHO, 2020b). Hastalı̆̆ın devam eden seyri boyunca; insanlar virüsün gidișatına tüm dikkatlerini vermiş ve her bir devlet salgınla etkili bir şekilde mücadele etmek adına çeşitli önlemler almıştır. Türkiye'de görülen ilk vaka 10 Mart 2020 tarihine tekabül etmektedir (T.C. Sağlık Bakanlığı, 2020). Hastalığın ortaya çıkışından 2 Temmuz 2020'ye dek; dünyada 10.533.779, Türkiye'de ise 201.098 birey enfekte olmuştur. Dünyadaki Covid-19'a bağlı ölüm sayısı 512.842 iken Türkiye'de görülen ölüm sayısı 5.150'dir (WHO, 2020c). 
Dünya tarihi covid-19 öncesinde, SARS, H1N1 gibi salgınlarla karşı karşıya kalmıştır ve ileride yeni salgınların da olabileceği öngörülmektedir. Bu bağlamda, ruh sağlığı çalışanlarının salgın hastalıkların ve beraberinde getirilen karantina gibi koruyucu önlemlerin yol açtığı psikolojik değişkenler hakkında bilgi sahibi olmaları önem arz etmektedir. SARS salgınının birinci dalgası sırasında gerçekleştirilen bir çalışmada (Nickell, Crighton, Tracy, Al-Enazy, Bolaji, Hanjrah, Hussain, Makhlouf ve Upshur, 2004: 793-798), katılımcıların üçte ikisi kendilerinin ve ailelerinin sağlıkları hakkında endişeli olduklarını bildirirken üçte birinde psikiyatrik morbidite gözlemlenmiştir. Bu bulgular Tayvan'da gerçekleştirilen başka bir çalışma (Chong, Wang, Hsieh, Lee, Chiu, Yeh, Huang, Wen ve Chen, 2004: 127-133) ile tutarlılık göstermektedir. Bahsi geçen çalışmada sağlık çalışanlarının \%75'inde psikiyatrik morbidite görülmüştür. Literatüre Covid-19'a özgü çalışmalar da eklenmeye başlamıştır. Bu salgın sırasında anksiyete ve depresyon dahil olmak üzere psikolojik rahatsızlıkların arttığı bildirilmiştir (Duan ve Zhu, 2020: 300-302). Çin'de gerçekleştirilmiş bir anket çalışmasında katılımcılar salgının psikolojik etkilerini değerlendirmiştir. Katılımcıların \%53.8'i salgının psikolojik etkilerini orta veya şiddetli olarak bildirirken, \%16.5'i depresif belirtiler ve \%28.8'i anksiyöz belirtiler göstermiştir (Wang, Pan, Wan, Tan, Xu, Ho ve Ho, 2020: 1-25). Doğrulanmış veya şüpheli Covid-19 hastaları kendilerini kaygılı hissedebilmektedir (de Medeiros Carvalho, Moreno Moreira, Arcanjo de Oliveira, Macedo Landim ve Rolim Neto, 2020) ve enfeksiyonun belirtileri var olan kaygının kötüleşmesine neden olabilmektedir (Xiang, Yang, Li, Zhang, Zhang, Cheung ve Ng, 2020: 228-229). Bireylerin deneyimlediği psikolojik korku; 17 yıl önceki SARS salgınına nazaran daha yoğunlaşmıştır. Günümüzde ülkeler arasında küresel bağlantıların mevcut olması ve insanların hava ulaşımını daha sık tercih etmesi pandeminin yayılmasını kolaylaştırmaktadır ve söz konusu psikolojik korkuya katkıda bulunur niteliktedir (Sh Ho, Yi Chee ve Cm Ho, 2020: 1-3). Gerek daha önce yaşanmış salgınların gerek şu anda içinde bulunulan Covid-19 sürecinin kayg1 uyandırmasının temelinde hastalığın kesin nedeninin bilinmemesinin yattığı varsayılmaktadır. $\mathrm{Bu}$ belirsizliğin psikiyatrik morbiditeyi arttırdığı düşünülmektedir (Poole, Hood, Davis, Monypenny, Sweetland, Webster, Lyons ve Mansel, 1999: 334-338; Thompson, Lopez, Lee ve Twinn, 2004: 131-135).

Literatürde yer alan açıklamalara bakıldığında; belirsizlik ve psikolojik rahatsızlıklar ile ilişkili olan belirsizliğe tahammülsüzlük kavramlarının önemi ortaya çıkmaktadır. Belirsizlik; Budner tarafindan (1962: 29-50), yetersiz ipuçları nedeniyle net bir şekilde temellendirilemeyen veya kategorilendirilemeyen durum olarak tanımlanmaktadır. Buhr ve Dugas (2002: 931-945), belirsizliğe tahammülsüzlüğü; belirsiz durumlara yönelik olumsuz tepkilerde bulunmak olarak açıklamaktadır. Buhr ve Dugas (2002: 931-945)'a göre belirsizliğe tahammülsüzlügü yüksek olan bireyler belirsiz durumlara karşı dört bakış açısı sunmaktadır: 1) Belirsizlik stresli ve sıkıntı veren bir olgudur. 2) Belirsiz bir durum, harekete geçmenin önüne geçmektedir. 3) Belirsiz durumlar negatiftir ve onlardan kaçınılamamaktadır. 4) Bir durumun net olmaması adeletsizliktir. Covid-19 süreci doğası gereği pek çok belirsizliği beraberinde getirmektedir. Belirsizliğe tahammülsüzlüğü yüksek olan bireylerin bu süreçte diğerlerine oranla daha fazla zorlanmaları muhtemeldir. Mevcut çalışmanın araştırmacıları, belirsizliğe tahammülsüzlüğ̈̈ yüksek olan bireylerin salgın ve karantina sürecini daha zorlanarak geçirdiğini tahmin etmektedir.

Hastalığın kendisinin yol açtığı olumsuz psikolojik çıtıların yanı sıra karantina gibi koruyucu önlemlerin etkileri de önem taşımaktadır. Karantinanın insanların psikolojisi üzerinde olumsuz etkilere sahip olduğuna dair çalışmalar mevcuttur (Bai, Lin, Lin, Chen, Chue ve Chou, 2004: 10551057; Liu, Kakade, Fuller, Fan, Fang, Kong, Guan ve Wu, 2012: 15-23; Sprang ve Silman, 2013: 105-110; Taylor, Agho, Stevens ve Raphael, 2008: 347; Wu, Fang, Guan, Fan, Kong, Yao, Liu, Fuller, Susser, Lu ve Hoven, 2009: 302-311). Kitle karantinasının, hastalığa dair duyulan kaygıyı arttırması muhtemeldir (Tavares Lima, de Medeiros Carvalho, Tavares Lima, de Oliveira Nunes, Saraiva, de Souza ve Neto, 2020: 1-10). Bunun yanı sıra, karantinaya alınan insanların sahip olduğu boş zaman miktarları artış göstermektedir. Tezcan (1982) boş zamanı, bireyin bütün

Turkish Studies 15(4) 
güçlüklerinden sıyrıldığı ve kendi iradesiyle seçtiği bir aktiviteyle uğraştığı zaman şeklinde tanımlamaktadır. Ancak, söz konusu boş zaman; bireylerin kendi yarattığı zamandan ziyade pandemi sürecinin ve zorunlu karantinanın getirdiği bir zaman dilimidir. Bu zorunlu boş zaman hali, beraberinde can sıkıntısını getirebilmektedir. $\mathrm{Bu}$ yüzden, karantinadaki bireylerin deneyimledikleri bir diğer olumsuz durum can sıkıntısıdır (de Medeiros Carvalho vd., 2020). Literatürde can sıkıntısı duygusu; yineleyen, arzu edilmeyen ve anlamsız olarak görülen durumlarda yaşanan duygusal bir zorluk olarak ifade edilmektedir (Eastwood, Fahlman, MercerLynn ve Flora, 2013: 68-85; Van Tilburg, Igou ve Sedikides, 2013: 450-461; van Tilburg ve Igou, 2011: 1679-1691; Smith, Wagaman ve Handley, 2009: 150-160; Mikulas ve Vodanovich, 1993: 312; Sansone, Weir, Harpster ve Morgan, 1992: 379-390). Boş zamanın fazla olması (Phillips, 1993: 1-23), bu zamanda gerçekleştirilecek etkinliklerin yeterli olmaması ya da gerçekleştirilen etkinliklerin tatmin ediciliğinin düşük olması ise boş zaman can sıkıntısı olarak isimlendirilmektedir (Iso-Ahola ve Weissinger, 1990: 1-17). Boş zaman can sıkıntısı, karantina sürecinin nasıl algılandığını etkileyebilmektedir. Mevcut çalışmanın araştırmacılarının bir diğer tahmini ise, boş zaman can sıkıntısı yüksek olan bireylerin salgın ve karantina sürecini daha zor geçirdiği yönündedir.

Karantina sürecinde evlerde bulunmak ve boş zamanın önemli ölçüde artış göstermesi, telefon kullanımının artmasına yol açabilmektedir. Ancak, telefon kullanımı pandemi öncesinde de yaygındı. Türkiye İstatistik Kurumu'nun (TÜİK) raporuna göre (2017); 16-74 yaşlarındaki bireylerin \%66.8'i internet kullanıcısıdır. Bu oran, bir önceki seneye göre \%5.6'lık bir artış göstermiştir (TÜiK, 2016). Bu durum, telefonların sağladığı avantajlar ile açılanabilir. Cep telefonları, bireylere internet aracılı̆̆ıyla bilgiye anında erişim ve başka firsatlar sunmaktadır (Kalecik, 2016). 2005 yılından itibaren internet, bilgi sağlama özelliğinin yanına kullanıcılara sosyal ortam sunma imkanını da eklemiştir (Erkul, 2009: 96-101; Kaplan ve Haenlein, 2009: 5968). Bu imkanlarla beraber internet ve sosyal medya kullanımı giderek yaygınlaşmış ve günlük yaşamın bir parçası haline gelmiştir (Aslan, 2020). Günümüzde tercih edilen sosyal medya uygulamalarının her birinin hitap ettiği kitle, kullanım amacı ve kullanım şekli birbirinden farklılık göstermektedir (Üçer, 2016: 1-26). WhatsApp; görüntü, video ve sesli veya yazılı mesaj aracılığıyla anlık iletişimi sağlayan bir sosyal medya uygulamasıdır (Awada, 2016: 1-25). YouTube video paylaşımını (Salkaya, 2020), Facebook sosyal etkileşimi, Instagram eğlenmeyi ve zaman geçirmeyi, Twitter ise haberlere ulaşmayı sağlamaktadır (Üçer, 2016: 1-26). Twitter, diğer uygulamalara nazaran, ağıllıklı olarak bilgiye ulaşmayı sağlar. Trendtopic mekanizması sayesinde hem ikamet edilen ülke hem de dünya genelindeki güncel konuları takip etmeyi kolaylaştırır. Pandemi sürecinde insanlar salgının gidişatı ile ilgili haberleri takip etmeye ihtiyaç duymaktadır. Bu bağlamda; Twitter kendine özgü kullanım amacı sayesinde pandemi döneminde diğer sosyal medya uygulamalarına kıyasla insanlar üzerinde daha çok etkiye sahip olacak gibi görünmektedir.

Telefon ve internet kullanımı problemli bir hale evrildikçe, beraberinde bazı sıkıntıları getirmektedir. Problemli telefon ve internet kullanımının zihinsel sağlik üzerinde olumsuz etkileri olduğu bilinmektedir (örn; Caplan, 2002: 553-575; Whang, Lee ve Chang, 2003: 143-150; Beranuy, Oberst, Carbonell ve Chamarro, 2009: 1182-1187; Roberts, Pullig ve Manolis, 2015: 13 19). Bu olumsuz etkilere depresyon, sosyal fobi (Yen, Ko, Yen, Wu, ve Yang, 2007: 93-98), anksiyete (Whang vd., 2003: 143-150), dürtüsellik (Lin, Ko ve Wu, 2011: 741-746), utangaçlik (Bian ve Leung, 2014: 61-79), duygu düzenleme sorunları (Şakiroğlu, 2019: 301-308) ve duygusal dengesizlik (Roberts vd., 2015: 13-19) örnek verilebilir. Literatürde yer alan bilgiler baz alındığında, pandemi sürecinde telefon ve internet kullanımının artış göstermesi bir risk faktörü olarak değerlendirilmektedir. Özetle, bu çalışmada insanların telefonları ile geçirdikleri süre artış gösterdikçe salgının ve karantinanın olumsuz etkisinin de artacağı düşünülmektedir.

Pandeminin ve zorunlu karantinanın getirdiği zorluklara karşı koruyucu olabilecek psikolojik faktörler oldukça önemlidir. Söz konusu faktörler, bireylerin psikolojik sağlığını 
korumalarını ve bu zorlu pandemi süreci ile başa çıkmalarını sağlayacaktır. Bu nedenle, risk faktörlerinin olduğu kadar koruyucu faktörlerin de tespit edilmesi gerekmektedir. Koruyucu faktör olabilecek kavramlardan bir tanesi doğa ile ilişki içerisinde olmaktır. Doğayla ilgili davranışlar ve nedenleri uzun zamandır psikologların araştırma konuları arasındadır (Çakır, Karaarslan, Şahin ve Ertepınar, 2015: 1370-1383). Doğa ve bahçe kavramları yaşam kalitesi ile oldukça ilişkilidir. İnsanlar doğa ile ilişki kurarken, aynı zamanda kendi gelişimi ile de bağ kurmaktadır. Dolayısıyla bitki bakımını üstlenmek; insan ile doğa arasındaki ilişkinin ve insanın kendisiyle olan ilişkisinin bir göstergesidir (Özdemir ve Kıray Vural, 2015: 65-77). Doğa ile ilişkili olmanın insan sağlığı üzerinde olumlu etkilerinin olduğu birçok araştırma tarafından kanıtlanmıştır (örn; Cole ve Hall, 2010: 806-823; Hartig, Johansson ve Kylin, 2003: 611-636; Cooper-Marcus ve Barnes, 1999: 323384; Sherman, Mc Cuskey Shepley ve Vami, 2005: 301-314; Whitehouse, Vami, Seid, CooperMarcus, Ensberg, Jacobs ve Mehlenbeck, 2001: 301-314). Doğaya zaman ayırmak stresi azaltmakta (Cole ve Hall, 2010: 806-823; Hartig vd., 2003: 611-636) ve bireylerin duygudurumunda iyileşme yaratmaktadır (Cooper-Marcus ve Barnes, 1999: 323-384; Sherman vd., 2005: 301-314; Whitehouse vd., 2001: 301-314). Bu nedenle, olağanüstü koşulları beraberinde getiren pandemi döneminde evde veya bahçede bitki yetiştiriyor olmak; koruyucu bir psikolojik faktör olarak değerlendirilebilir. Bu noktada araştırmacılar; insanların bitkileri ile geçirdikleri zaman arttıkça belirsizliğe tahammülsüzlük ile boş zaman can sıkıntısı düzeylerinin ve salgın ile karantinanın olumsuz etkisinin azalacağını varsaymaktadır.

İnsan-doğa ilişkisindeki en önemli boyutlardan biri, diğer canlı türleri ile kurulan ilişkidir. Bu ilişkide hayvanlar, oldukça özel bir konuma sahiptir (Büyükcebeci ve Y1lmaz, 2019). Evcil hayvanlar; sevgi nesnesi, yalnızlığı giderme, duyguları regüle etme gibi işlevlere sahiptir (Suna, 2019). Bununla birlikte, son zamanlarda evcil hayvan sahiplenen bireylerin sayısında artış gözlenmiştir (Guthrie, Marshall, Hendrick, Hendrick ve Logue, 2018: 41-60). Psikoloji alanında yürütülen çalışmalarda evcil hayvan sahibi olmanın ilişki kurma ihtiyacı, yalnızlık duygusu (Andreassen, Stenvold ve Rudmin, 2013: 6-23) ve bazı patolojiler üzerinde iyileştirici gücü (Antonacopoulos ve Pychyl, 2010: 37-54) araştırılmaktadır. Sosyal desteğin kısitlı olduğu koşullarda, evcil hayvanları ile güçlü bağlar kurmuş olan yaşlı bireylerin, diğerlerine nazaran daha düşük depresif ve anksiyöz belirtiler deneyimlediği ve daha iyi bir fiziksel sağlığa sahip olduğu rastlanan çalışma bulguları arasındadır (Garrity, Stallones, Marx ve Johnson, 1989: 35-44). Zorunlu karantina durumu beraberinde sınırlı sosyal ilişkileri getirdiğinden ötürü, psikolojik sağlık için evcil hayvan sahibi olmak önem arz etmektedir. Bu bilgiler 1şığında araştırmacılar; insanların hayvanları ile geçirdikleri zaman arttıkça belirsizliğe tahammülsüzlük ile boş zaman can sıkıntısı düzeylerinin ve salgın ile karantinanın olumsuz etkisinin azalacağını düşünmektedir.

$\mathrm{Bu}$ çalışmanın amacı, 18-65 yaş arasındaki bireylerde salgının ve karantinanın psikolojik etkilerinin incelenmesidir. Çalışmanın amacı doğrultusunda, bulgular bölümünde sınanmak üzere 5 hipotez kurulmuştur:

1. Belirsizliğe Tahammülsüzlük Ölçeği'nden alınan puanlar yükseldikçe Olayın Etkisi Ölçeği'nden alınan puanların da yükselmesi beklenmektedir $\left(R^{2} \geq 0.13\right)$.

2. Boş Zaman Can Sıkıntısı Ölçeği'nden alınan puanlar yükseldikçe Olayın Etkisi Ölçeği'nden alınan puanların da yükselmesi beklenmektedir $\left(R^{2} \geq 0.13\right)$.

3. Telefon ile geçirilen süre arttıkça, Olayın Etkisi Ölçeği'nden alınan puanların da yükselmesi beklenmektedir $\left(R^{2} \geq 0.13\right)$.

4. Evcil hayvan sahibi olan bireylerin Belirsizliğe Tahammülsüzlük, Boş Zaman Can Sıkıntısı ve Olayın Etkisi Ölçeklerinden aldıkları puanların, evcil hayvan sahibi olmayan bireylerin aldıkları puanlardan daha düşük olması beklenmektedir $(\mathrm{d} \geq 0.5)$. 
5. Bitki sahibi olan bireylerin Belirsizliğe Tahammülsüzlük, Boş Zaman Can Sıkıntısı ve Olayın Etkisi Ölçeklerinden aldıkları puanların, bitki sahibi olmayan bireylerin aldıkları puanlardan daha düşük olması beklenmektedir $(\mathrm{d} \geq 0.5)$.

\section{Yöntem}

\section{Katılımcilar}

Bu çalışmaya 18-65 yaşları arasında 372 kişi katılmıştır. 15 kişi yapılan analizlerde uç değer haline gelip sonuçları bozması nedeniyle çalışmadan çıkarılmıştır. Örneklemin son halini 251 kadın, 106 erkek olmak üzere 357 kişi oluşturmaktadır. Katılımcıların yaş ortalaması 43.32'dir (SS = 11.54). Veriler, Aydın Adnan Menderes Üniversitesi'nin pandemi sirasinda memleketlerine dönen psikoloji ile psikolojik danışmanlık ve rehberlik bölümleri öğrencilerinin vasıtasıyla toplanmıştır. Toplam 61 ilden katılımcı mevcuttur. En çok katılımcı sayısına sahip ilk 3 il sırasıyla; İzmir $(n=47, \% 13,17)$, Aydın $(n=43, \% 12,04)$ ve Bursa'dir $(n=29, \% 8,12)$. Katılımciların $\% 80,1$ 'i $(n=286)$ en az bir bitki sahibiyken, \%19,9'unun $(n=71)$ bitkisi bulunmamaktadır. Katılımcılardan \%26,3'ünün $(n=94)$ evcil hayvanı varken \%73,7'si $(n=263)$ herhangi bir hayvana sahip değildir.

\section{Ölçekler}

\section{Evcil Hayvan ve Bitki Sahipliği ile Telefon Kullanımı Hakkındaki Sorular:}

$\mathrm{Bu}$ form, standart bir ölçek olmayıp araştırmacılar tarafından mevcut çalışmada kullanılmak üzere hazırlanmıştır. Evcil hayvanlar konusunda katılımcılara evcil hayvanlarının olup olmadığ1 sorulmuştur. Bitki için katılımcılara; bitkilerinin olup olmadığı sorulmuştur. Telefon kullanımına yönelik sorulan sorular; telefonda ne kadar süre geçirildiği, telefonda geçirilen sürenin pandemi öncesine göre değiş̧ip değişmediği ve telefonda hangi sosyal medya uygulamalarının (Instagram, Twitter, WhatsApp, Facebook, YouTube) yüklü olduğudur.

\section{Belirsizliğe Tahammülsüzlük Ölçeği-12:}

Carleton, Norton ve Asmundson (2007: 105-117) tarafından geliştirilmiştir ve 12 maddeden oluşmaktadır. Geleceğe dönük kaygı ve engelleyici kaygı olmak üzere iki alt ölçeği vardır. Yetişkinler için geliştirilmiş bu özbildirim (self-report) ölçeğinin soruları 5'li Likert ("1" Bana hiç uygun değil, "2" Bana çok az uygun, "3" Bana biraz uygun, "4" Bana çok uygun ve "5" Bana tamamen uygun) cevap seti üzerinde yanıtlanmaktadır. Sarıçam, Erguvan, Akın ve Akça (2014: 148-157) tarafından Türkçeye çevrilen ölçeğin güvenirlik ve geçerliğinin yüksek olduğu gösterilmiştir. İç tutarlılık güvenirliği Cronbach Alfa katsayısları ölçeğin orijinal versiyonu için .96, Türkçe çevirisi için .74 olarak bulunmuştur. Mevcut çalışma için Cronbach Alfa katsayısı .84 olarak hesaplanmıştır.

\section{Boş Zaman Can Sıkıntısı Ölçeği:}

Iso-Ahola ve Weissinger (1990: 1-17) tarafindan geliştirilmiştir ve 16 maddeden oluşmaktadır. Yetkinlik ve motivasyon olmak üzere iki alt ölçeği vardır. 5'li Likert ("1" Kesinlikle katılmıyorum, "2" Katılmıyorum, "3" Kararsızım, "4" Katılıyorum, "5" Kesinlikle Kat1lyorum) skalası üzerinde yanıtlanmaktadır. Soylu ve Siyez (2014: 80-95) tarafından Türkçeye uyarlanmıştır. Ölçeğin Türkçe versiyonunda 12 madde bulunmaktadır. Ölçeğin orjinal versiyonunun Cronbach Alfa katsayısı .85, Türkçe uyarlamasının Cronbach Alfa katsayısı .84 olarak bulunmuştur. Mevcut çalışma için Cronbach Alfa katsayısı .86 olarak hesaplanmıştır.

\section{Olayın Etkisi Ölçeği:}

Weiss ve Marmar (1997: 399-411) tarafından geliştirilmiş ve 22 maddeden oluşmaktadır. Yeniden yaşama, kaçınma ve aşırı uyarılma olmak üzere 3 alt ölçeği vardır. 5'li Likert ("0" Asla, "1" Biraz, "2" Az çok, "3" Oldukça ve "4" Aşırı) skalası üzerinde yanıtlanmaktadır. Ölçek 
Çorapçıŏlu, Yargıç, Geyran ve Kocabaşoğlu (2006: 14-22) tarafından Türkçe’ye çevrilmiştir. Ölçeğin orjinal versiyonunun Cronbach Alfa katsayısı .96, Türkçe çevirisinin Cronbach Alfa katsayıs1 .94 olarak bulunmuştur. Mevcut çalışma için Cronbach Alfa katsayısı .87 olarak hesaplanmıştır.

\section{İşlem}

$\mathrm{Bu}$ çalışma, Aydın Adnan Menderes Üniversitesi Sosyal ve Beşeri Bilimler Etik Kurulu tarafından (Etik Kurul Onay Kodu: 31906847/050.04.04-08/14) onaylanmıştır. Mevcut çalışma kesitsel ve alan araştırmasına dayalı bir araştırmadır. Aydın Adnan Menderes Üniversitesi öğrencilerinin vasıtasıyla ulaşılan aile büyükleri araştırmanın örneklemini oluşturmaktadır. Bilgilendirilmiş onam formuna onay veren katılımcılara, sosyodemografik bilgi formunu ve araştırmada kullanılan ölçekleri (Belirsizliğe Tahammülsüzlük Ölçeği-12, Boş Zaman Can Sıkıntısı Ölçeği ve Olayın Etkisi Ölçeği) içeren bir anket formu uygulanmıştır.

Veriler pandeminin 69-76. (18 Mayıs- 25 Mayıs 2020) günleri arasında toplanmıştır. Elde edilen veriler Statistical Packages for the Social Sciences-22 (SPSS-22) programı kullanılarak analiz edilmiştir. İstatistiksel anlamlılık düzeyi .05 olarak benimsenmiştir. Evcil hayvan sahibi olan ve olmayan bireylerin araştırmada kullanılan ölçeklerden aldıkları puanları karşılaştırmak amacıyla bağımsız örneklem $t$ test analizi uygulanmıştır. Aynı analiz, bitki sahibi olan ve olmayan bireylerin ölçek puanlarını karşılaştırmak üzere uygulanmıştır. Olayın Etkisi Ölçeği'nden alınan puanları yordayan değişkenleri saptamak üzere linear regresyon analizi yapılmıştır. Regresyonun ön koşulu olarak ölçekler arasındaki korelasyon hesaplanmıştır.

\section{Bulgular}

Yapılan araştırmada öncelikle verinin dağılımını sınamak amacıyla Kolmogorov-Smirnov normallik analizi yapılmış, örneklemin normal dağılım gösterdiği saptanmıştır $(p>.05)$.

\section{Evcil Hayvan Sahibi Olma Durumuna Göre Karşılaştırmalar}

Tablo 1: Evcil hayvan sahibi olan ve olmayan bireylerin belirsizliğe tahammülsüzlük puan ortalamalarındaki farklılaşmaya ait bağımsız örneklemler için t testi analizi sonuçları

\begin{tabular}{lrccccc}
\hline Evcil Hayvan & $n$ & $\bar{x}$ & s.s & s.d & $t$ & $p$ \\
\hline Var & 98 & 36,72 & 7,62 & 349 & $-2,61$ & $.009 *$ \\
Yok & 259 & 39,17 & 7,74 & & & \\
\hline$* p<.05$ & & & & &
\end{tabular}

Evcil hayvan sahibi olan ve olmayan bireylerdeki belirsizliğe tahammülsüzlük düzeyinde bir farklılaşma olup olmadığını saptamak amacıyla yapılan bağımsız örneklemler için t testi sonuçlarına göre, evcil hayvan sahibi olan bireylerin belirsizliğe tahammülsüzlük puan ortalamaları $(\bar{x}=36,72)$ ile evcil hayvan sahibi olmayan bireylerin belirsizliğe tahammülsüzlük puan ortalamaları $(\bar{x}=39,17)$ arasında istatistiksel olarak anlamlı bir farklılaşma görülmüştür $\left[t_{(349)}=-\right.$ $2,61, p<.05]$.

Tablo 2. Evcil hayvan sahibi olan ve olmayan bireylerin boş zaman can sıkıntısı puan ortalamalarındaki farklılaşmaya ait bağımsız örneklemler için t testi analizi sonuçları

\begin{tabular}{lcccccc}
\hline Evcil Hayvan & $n$ & $\bar{x}$ & s.s & s.d & $t$ & $p$ \\
\hline Var & 98 & 36,57 & 4,22 & 349 &,- 36 & $.72^{*}$ \\
Yok & 259 & 36,76 & 4,20 & & & \\
\hline
\end{tabular}

$* p>.05$ 
Evcil hayvan sahibi olan ve olmayan bireylerdeki boş zaman can sıkıntısı düzeylerinde bir farklılaşma olup olmadığını saptamak amacıyla yapılan bağımsız örneklemler için t testi sonuçlarına göre, evcil hayvan sahibi olan bireylerin boş zaman can sıkıntısı puan ortalamaları $(\bar{x}=$ $36,57)$ ile evcil hayvan sahibi olmayan bireylerin boş zaman can sıkıntısı puan ortalamaları $(\bar{x}=$ $36,76)$ arasında istatistiksel olarak anlamlı bir farklılaşma görülmemiştir $\left[t_{(349)}=-, 36, p>.05\right]$.

Tablo 3: Evcil hayvan sahibi olan ve olmayan bireylerin olayın etkisi ölçeğinden aldıkları puan ortalamalarındaki farklılaşmaya ait bağımsız örneklemler için t testi analizi sonuçları

\begin{tabular}{lrccccc}
\hline Evcil Hayvan & $n$ & $\bar{x}$ & s.s & s.d & $t$ & $p$ \\
\hline Var & 98 & 49,95 & 12,05 & 349 & $-2,25$ & $.025^{*}$ \\
Yok & 259 & 53,15 & 11,58 & & & \\
\hline
\end{tabular}

$* p<.05$

Evcil hayvan sahibi olan ve olmayan bireylerin olayın etkisi ölçeğinden aldıkları puanların ortalamaları arasında anlamlı bir farklılaşma olup olmadığını saptamak amacıyla yapılan bağımsız örneklemler için t testi sonuçlarına göre, evcil hayvan sahibi olan bireylerin olayın etkisi ölçeği puan ortalamaları $(\bar{x}=49,95)$ ile evcil hayvan sahibi olmayan bireylerin olayın etkisi ölçeği puan ortalamaları $(\bar{x}=53,15)$ arasında istatistiksel olarak anlamlı bir farklılaşma görülmüştür $\left[t_{(349)}=\right.$ $2,25, p<.05]$.

\section{Bitki Yetiştirme Durumuna Göre Karşılaştırmalar}

Bitki yetiştirme durumuna göre belirsizliğe tahammülsüzlük, boş zaman can sıkıntısı ve olayın etkisi ölçeklerinden alınan puanların ortalamalarının karşılaştırılması amacıyla her bir ölçek için bağımsız örneklemler için $\mathrm{t}$ test analizi gerçekleştirilmiştir. Analizin sonucunda, bitki yetiştiren ve yetiştirmeyen bireyler arasında belirsizliğe tahammülsüzlük, boş zaman can sıkıntısı ve olayların etkisi puan ortalamaları arasında istatistiksel olarak anlamlı bir farklılaşma görülmemiştir $(p>.05)$.

\section{3. Ölçekler Arası Korelasyonlar}

Tablo 4: Olayın Etkisi Ölçeği, Boş Zaman Can Sıkıntısı Ölçeği ve Belirsizliğe Tahammülsüzlük Ölçekleri arasındaki korelasyonlar

\begin{tabular}{lccc}
\hline Ölçekler & OEÖ & BZCSÖ & BTÖ \\
\hline OEÖ & 1 & $.26^{*}$ & $.30^{*}$ \\
BZCSÖ & $.26^{*}$ & 1 & $.16^{*}$ \\
BTÖ & $.30^{*}$ & $.16^{*}$ & 1 \\
\hline
\end{tabular}

OEÖ: Olayın Etkisi Ölçeği, BZCSÖ: Boş Zaman Can Sıkıntısı Ölçeği, BTÖ: Belirsizliğe Tahammülsüzlük Ölçeği

$* p<.001$

Ölçekler arasındaki ilişkiyi belirlemek amacıyla yapılan korelasyon analizi sonuçlarına göre, Olayın Etkisi Ölçeği (OEÖ) ile Boş Zaman Can Sıkıntısı Ölçeği (BZCSÖ) arasında istatistiksel olarak anlamlı ve pozitif bir ilişki $(r=.26, p<.001)$, Olayın Etkisi Ölçeği (OEÖ) ile Belirsizliğe Tahammülsüzlük Ölçeği (BTÖ) arasında istatistiksel olarak anlamlı ve pozitif bir ilişki $(r=.30, p<.001)$, Boş Zaman Can Sıkıntısı Ölçeği (BZCSÖ) ile Belirsizliğe Tahammülsüzlük (BTÖ) ölçeği arasında ise istatistiksel olarak anlamlı ve pozitif bir ilişki $(r=.16, p<.001)$ saptanmıştır. 


\section{Regresyon Analizi}

Bireylerin olaydan etkilenme düzeyleri üzerinde etkili olduğu düşünülen cinsiyet, ev ortamı, sosyoekonomik statü, telefon kullanım süresi, sosyal medya uygulamaları (Whatsapp, Facebook, Twitter, İnstagram ve Youtube), belirsizliğe tahammülsüzlük ve boş zaman can sıkıntısı değişkenlerinin, bireylerin salgın ve karantinadan etkilenme düzeyleri üzerindeki etkisini incelemek amacıyla linear regresyon analizi yapılmıştır. Yapılan regresyon analizinde stepwise metodu kullanılmıştır. Analiz sonucunda anlamlı çıkan değişkenler Tablo 5 'te verilmiştir.

Tablo 5: Olayın Etkisi Ölçeği için Regresyon Analiz Modeli

\begin{tabular}{lccccc}
\hline Değişken & $\mathrm{B}$ & s.h. & $\beta$ & $t$ & $p$ \\
\hline Sabit & 25.50 & 6.77 & & 3.76 & .000 \\
Ev Ortamı & $-3,20$ & 1.04 &,- 14 & -3.07 & .002 \\
Sosyoekonomik Düzey & -2.32 & .93 &,- 11 & -2.48 & .014 \\
Twitter & -.55 & .25 & -.10 & 2.20 & .028 \\
Telefon süresi & 1.97 & .65 & .14 & 3.03 & .003 \\
$\begin{array}{l}\text { Belirsizliğe } \\
\text { tahammülsüzlük }\end{array}$ & .44 & .07 & .28 & 5.94 & .000 \\
$\begin{array}{l}\text { Boş zaman } \\
\text { can sikıntı1 }\end{array}$ & .57 & .13 & .20 & 4.27 & .000 \\
\hline $\mathrm{R}=.50$ & & & & \\
$\mathrm{~F}_{(6-357)}=18.98$ & & $\mathrm{R}^{2}=.23$ & & \\
\hline
\end{tabular}

Cinsiyet, ev ortamı, sosyoekonomik statü, telefon kullanım süresi, sosyal medya uygulamaları (Whatsapp, Facebook, Twitter, İnstagram ve Youtube), belirsizliğe tahammülsüzlük ve boş zaman can sıkıntısı değişkenlerinin, bireylerin salgın ve karantinadan etkilenme düzeyi üzerindeki etkisini incelemek amaciyla yapılan regresyon analizine göre; ev ortam1, sosyoekonomik statü, telefon kullanım süresi, sosyal medya uygulamalarından Twitter, belirsizliğe tahammülsüzlük ve boș zaman can sıkıntısı değișkenleri birlikte, olayın etkisi değișkeni ile anlamlı bir ilişki $\left(\mathrm{R}=.50, \mathrm{R}^{2}=.23\right)$ sergilemişlerdir $\left(\mathrm{F}_{(6-357)}=18.98, p<.01\right)$. Bu altı değişken birlikte olayın etkisi puanlarındaki değişimin \%23'ünü açıklamaktadır. Standartlaştırılmış regresyon katsayılarına göre, yordayıcı değişkenlerin olayın etkisi üzerindeki önem sırası belirsizliğe tahammülsüzlük $(\beta=.28)$, boş zaman can sıkıntısı $(\beta=.20)$, telefon süresi $(\beta=.14)$, ev ortamı $(\beta=$ $.14)$, sosyoekonomik statü $(\beta=.11)$ ve Twitter $(\beta=.10)$ olarak saptanmıştır. Yordayıc1 değişkenlerin anlamlılık testine bakıldığında, cinsiyet ve bazı sosyal medya uygulamaları (Whatsapp, Facebook, İnstagram ve Youtube) dışındaki diğer değişkenlerin olayın etkisi üzerinde anlamlı yordayıcılar olduğu görülmektedir.

\section{Tartışma}

Dünya genelinde yaklaşık üç buçuk aydır devam eden Covid-19 salgını yaşamda büyük değişikliklere yol açmıştır. Salgın hastalıkların ve karantinanın bazı psikolojik çıktılar ortaya koyduğu çalışmalarca gösterilmiştir (Maunder, Hunter, Vincent, Bennett, Peladeau, Leszcz, Sadavoy, Verhaeghe, Steinberg ve Mazzulli, 2003: 1245-1251; Nickell vd., 2004: 793-798; Cohen ve Anderson, 1986: 321-326; Mihashi, Otsubo, Yinjuan, Nagatomi, Hoshiko ve Ishitake, 2009: 91; Marjanovic, Greenglass ve Coffey, 2007: 991-998; Hawryluck, Gold, Robinson, Pogorski, Galea ve Styra, 2004: 1206-1212). Covid-19 salgınında diğer salgın süreçlerine paralel olarak, psikolojik sonuçların görüleceği düşünülmektedir. Mevcut çalışmada, önemli olduğu düşünülen bazı psikolojik değişkenlerin üzerinde durulmuştur.

Yapılan bağımsız örneklemler için t testine göre; evcil hayvan sahibi olan bireylerin evcil hayvan sahibi olmayan kişilere nazaran salgından ve karantina sürecinden daha az etkilendikleri söylenebilmektedir. Aynı zamanda, evcil hayvan sahibi bireylerin belirsizliğe tahammülsüzlük düzeyleri daha düşüktür. Mevcut bulguları patoloji bağlamında değerlendirmek gerekirse; 
araştırmada kullanılan Olayın Etkisi Ölçeği ilk etapta travma sonrası stres bozukluğuna özgü geliştirilmiştir (Horowitz, Wilner ve Alvarez, 1979: 209-218). Belirsizliğe tahammülsüzlük ise, kaygının yordayıcılarından birisidir (Fergus ve Wu, 2011: 446-458; Khawaja ve McMahon, 2011: 165-180; Mahoney ve McEvoy, 2012: 26-39). Literatürde yer alan bir diğer bilgi; evcil hayvanların bireylerin psikolojik sağlıkları üzerinde koruyucu etkisi olduğudur (Berget, Ekeberg ve Braastad, 2008: 9; Banks, Willoughby ve Banks, 2008: 173-177; Antonacopoulos ve Pychyl, 2010: 37-54; Berget, Ekeberg, Pedersen ve Braastad, 2011: 50-64; Himsworth ve Rock, 2013: 295-305; Amiot ve Bastian, 2015: 6). Tüm bu bilgilerin 1şığında; çalışmada evcil hayvanın koruyucu faktör olarak işlev göstermesi anlam kazanmaktadır. Ancak, evcil hayvan sahibi olan bireylerin boş zaman can sıkıntısı düzeyleri ile evcil hayvan sahibi olmayanların puanları arasında herhangi bir farklılaşma görülmemiştir. Evcil hayvanlar, tıpkı insanlar gibi, içinde bulundukları ailenin bir üyesidirler (Yeşilkayalı ve Ofluoğlu, 2018: 1203-1219). Boş zamanı daha eğlenceli hale getirmek için ilgilenilecek bir araç olarak görülmemektedirler. Bu perspektiften bakıldığı takdirde, boş zaman can sıkıntısı düzeyinin değişmemiş olması akla yatkın görünmektedir.

Bitki sahibi olan ve olmayan bireylerin ölçek puanları birbirleri ile karşılaştırıldığında, herhangi bir farklılaşmanın söz konusu olmadığı tespit edilmiştir. Literatüre bakıldığı zaman, bitkilerin psikolojik yararları olduğu görülmektedir (Ulrich ve Parson, 1992: 93-105; Beer, 1990). Çalışmanın bulgusu literatür ile uyuşmamaktadır. Bu uyuşmazlığın nedeni çalışmanın örneklemi ile açıklanabilir. Bitki sahibi olan katılımcıların \%74.83'ü kadındır $(n=214)$ ve bu kadınların büyük bir çoğunluğu çalışmamaktadır (\%67.29, $n=144)$. Bahsi geçen kadınlar, pandemi öncesinde de zamanlarının büyük bir kısmını evde geçirmekteydiler. Bu yüzden; mevcut çalışmada evde kalıp bitki yetiştirmek pandemi dönemine özgü bir davranış olarak ortaya çıkmamış olabilir. Olağan rutinin bir parçası olan bitki bakımı, ölçek puanları arasında herhangi bir farklılaşmanın olmamasını açıklar niteliktedir.

Yapılan regresyon analizi sonucunda; belirsizliğe tahammülsüzlük, boş zaman can sıkıntısı, ev ortamı, sosyoekonomik düzey, telefon ile geçirilen süre ve twitter kullanımı salgının ve karantinanın etkisini yordayan değişkenler olarak bulunmuştur. Covid-19 salgını, insanların yeni tanışmış olduğu ve birçok belirsizliği barındıran bir durumdur. Bulaşma yolları ve hastalığın doğası kesin olarak bilinememektedir. Tedavisi için araştırmalar devam etmektedir. Aynı zamanda zorunlu karantinanın ne kadar süreceği veya bittiğinde bir daha gelip gelmeyeceği konusu da bir soru işaretidir. Bu belirsizlik durumu, psikolojik rahatsılıkları attırabilecek düzeydedir (Poole vd., 1999: 334-338; Thompson vd., 2004: 131-135). Psikolojik bir rahatsızlı̆ga sebebiyet vermese bile olumsuz duygulara yol açabilmektedir. $\mathrm{Bu}$ duygulardan birisi kaygıdır. Belirsizlik arttıkça bireylerin kayg1 düzeyleri de yükselmektedir (Buhr ve Dugas, 2006: 222-236; Norr, Oglesby, Capron, Raines, Korte ve Schmidt, 2013: 136-142). Belirsizliğin süregeldiği ve kaygının yoğunlaştığı durumlarda felaketleştirme senaryoları ortaya çıkmaktadır. Böylelikle kısır bir döngü meydana gelmektedir. Bu açıdan belirsizliğe tahammülsüzlüğün salgının ve karantinanın olumsuz etkisini yordaması makul görünmektedir. Covid-19 salgını beraberinde yalnızca belirsizliği getirmemekte, aynı zamanda bireylerin boş zamanlarının oldukça artmasına neden olmaktadır. Normal koşullar söz konusu olduğunda, insanlar boş zamanlarını çeşitli aktiviteler vasıtasıyla değerlendirebilmekte ve can sıkıntılarını azaltabilmektedirler (Harrison, 2005: 21-23). Boş zaman verimli olarak geçirilemediği takdirde, psikolojik sıkıntılar gündeme gelebilmektedir (Atmaca, 1997: 326-336). Pandemi süreci doğası gereği boş zaman süresinde çeşitli aktivitelerin gerçekleştirilmesini engellemektedir. Boş zaman can sıkıntısının, salgının ve karantinanın olumsuz etkisini yordaması bu şekilde açıklanabilir.

Bir diğer değişken olan ev ortamı irdelendiğinde; yaşanılan ortamın sağladığı hareket alanından bahsedilebilir. Mevcut çalışmanın katılımcıları ev ortamlarını; "müstakil ev", "balkonlu ev" veya "balkonsuz ev" olarak belirtmişlerdir. Müstakil evde oturan katılımcıların, diğer katılımcılara göre salgın ve karantina sürecinden daha az etkilendiği görülmektedir. Müstakil ev, 
bireylere daha geniş bir yaşam ortamı ve daha fazla hareket alanı sunmaktadır. Müstakil evin sağladığı bu avantaj etkili olmuş gibi görünmektedir. Salgın ve karantina üzerinde etkili olabilecek tek sosyodemografik değişken ev ortamı değildir. Sosyoekonomik düzey de önemli bir sosyodemografik değişkendir (Tatlılıoğlu, 2015: 1-15). Çalışmanın katılımcıları sosyoekonomik düzeylerini "gelirim giderimden az", "gelirim ile giderim birbirine eşit" veya "gelirim giderimden fazla" şeklinde belirtmişlerdir. Salgından ve karantinadan en az etkilenen grup geliri giderinden fazla olan grup olmuştur. Bu durum, koruyucu önlemlerin ve sağlık hizmetlerinin ekonomik bedelleri ile açıklanabilir. İnsanlar kendilerini korumak için maske, el dezenfektanı, siperlik gibi malzemelere ihtiyaç duymaktadır. Tüm bu önleyici uygulamalar, maddi imkanları gerektirmektedir. Ekonomik bedeller sadece giderlerle sınırlı değildir. Birçok sektör pandeminin getirdiği kısıtlamalar nedeniyle zor duruma düşmüş (Üstün ve Özçiftçi, 2020: 142-153) ve bazı çalışanlar bu süreçte işsiz kalmışlar veya maaşlarını alamamışlardır. Açıklanan bütün durumlar göz önüne alındığında, salgından ve karantinadan en az etkilenen bireylerin geliri görece daha iyi olan gruba mensup olması şaşırtıcı değildir.

Salgının ve karantinanın olumsuz etkilerini yordayan diğer değişkenler, telefon ile geçirilen süre ve twitter kullanımıdır. İnsanların boş zamanlarını değerlendirecek aktif bir uğraşlarının olmaması, telefon kullanım sürelerini arttırabilmektedir. Telefon kullanım süresinin artması, problemli telefon kullanım riskini ortaya çıkarmaktadır. Telefon kullanımı sürekli ve kontrol edilemez şekilde sosyal ağların takip edilmesi biçimini aldığ zaman; problemli telefon kullanımından söz edilebilmektedir (Ertem, 2006). Regresyon analizinin sonucunda, hem telefon kullanım süresi hem de twitter kullanımı arttıkça salgının ve karantinanın olumsuz etkilerinin arttığı bulunmuştur. Bu durum internetin ve özellikle twitter uygulamasının kontrolsüz biçimde kullanılması ile açıklanabilir. Araştırmaya dahil edilen diğer sosyal medya uygulamaları (WhatsApp, Youtube, Instagram ve Facebook), salgının ve karantinanın etkisini yordamamaktadır. $\mathrm{Bu}$ durum, sosyal medya uygulamalarının kendine has özellikleri ile ifade edilebilir. Mevcut makalenin giriş kısmında bahsedildiği üzere; her bir sosyal medya uygulaması bireylerin farklı bir ihtiyacını karşılamaktadır. Twitter haricindeki uygulamalar, bireyler ile pandemi arasına bir mesafe koymuş ve bireylerin kaygısını azaltmış olabilir. Twitter, pandemi döneminde salgın ile gelişmeleri takip etmek amacıyla tercih edilmiş olabilir. Bu bağlamda entübe bireylerin videoları, salgınla ilgili olumsuz gelişmeler ve bilgi kirliliğine yol açan paylaşımlar kişilerin olumsuz etkilenmesine sebebiyet vermiş olabilir.

Regresyon analizine giren fakat salgının ve karantinanın olumsuz etkilerini yordamayan diğer değişken, cinsiyettir. Literatüre bakıldığında kadınların salgın ve karantinadan daha fazla etkilendiği yönünde bulgular vardır (Liu, Zhang, Wei, Jia, Shang, Sun, Wu, Sun, Zhou ve Liu, 2020: 1-21; Wu, Chan ve Ma, 2005: 39-42; Gómez-Salgado, Andrés-Villas, Domínguez-Salas, Díaz-Milanés ve Ruiz-Frutos, 2020: 1-16). Ancak bu çalışma ilgili literatürün aksine bu açıdan kadınlar ve erkekler arasında bir farklılığın olmadığını göstermiştir. Bu bilgiden hareketle pandemi döneminde psikolojik sağlamlık, travma sonrası stres bozukluğu gibi değişkenlerin cinsiyet faktörü açısından irdelenmesi, konuya açıklık getirmesi bakımından önemli görülmektedir.

Mevcut çalışma birtakım sınırlılıklara sahiptir. İlk olarak, çalışmada kullanılan ölçeklerin pandemi sürecine özel geliştirilmiş ölçekler olmaması bir sınırlılıktır. Bir diğer kısıtlılık ise, araştırmanın kesitsel desen ile yürütülmüş olmasıdır. Araştırmanın yürütülmesi için seçilen desen nedeniyle, katılımcıların pandemi öncesi veya pandemi sonrası puanlarını almak mümkün olmamıştır. Bu nedenle bulgular daha dar bir perspektif çerçevesinde yorumlanmıştır. Son olarak, katılımcıların cinsiyeti homojen dağılım göstermemektedir. Bu yüzden elde edilen sonuçlar yanlılık gösterebilir.

Çalışmanın güçlü yanları da mevcuttur. İlk olarak, yüz yüze veri toplama yönteminin neredeyse imkansız hale geldiği bu süreçte çoğu araştırmacı verilerini çevrimiçi toplamak zorunda kalmıştır. Çevrimiçi veri toplama yöntemi bulguların güvenirliğini düşürebilmektedir. Ancak bu 
çalışmada veriler Aydın Adnan Menderes Üniversitesi'nin psikoloji ve psikolojik danışmanlık ve rehberlik bölümlerindeki öğrenciler vasıtasıyla toplanmıştır. Böylelikle bulguların güvenirliği korunmaya çalışılmıştır. Verilerin 61 ilden toplanmış olması başka bir güçlü özelliktir. Bu sayede şehirler ve bölgeler arasında görülebilecek farklılıkların önüne geçildiği ve çalışmanın genellenebilirliğinin arttırıldığ 1 düşünülmektedir.

Gelecekteki çalışmalar için bazı öneriler sunulmaktadır. Daha sağlıklı verilerin elde edilmesi adına boylamsal çalışmalar yapılmalıdır. Bir diğer öneri, örneklemi oluştururken kadın ve erkek katılımcıların denk olmasına özen gösterilmesidir. Böylelikle cinsiyet etkisi karıştırıcı değişken olmaktan çıkacaktır. Son olarak, normalleşme sürecinin ilerleyen zamanlarında internet erişimi olmayan bireyler ile yüz yüze çalışmalar gerçekleştirilmelidir.

\section{Kaynakça}

Alipour, A. (2020). The path analysis model in prediction of corona phobia based on intolerance of uncertainty and health anxiety. Journal of Research in Psychological Health, 14(1), 1-15.

Amiot, C. E., \& Bastian, B. (2015). Toward a psychology of human-animal relations. Psychological Bulletin, 141(1), 1-43. https://dx.doi.org/10.1037/a0038147

Andreassen, G., Stenvold, L. C., \& Rudmin, F. W. (2013). My dog is my best friend: Health benefits of emotional attachment to a pet dog. Psychology \& Society, 5(2), 6-23.

Antonacopoulos, D., \& Pychyl, T. A. (2010). Examining the role of pet ownership, human social support, pet attachment in psychological health of individuals living alone. Anthrozoös, 23, 37-54. https://dx.doi.org/10.2752/175303710X12627079939143

Aslan, T. (2020). Üniversite öğrencilerinin sosyal medya kaygllarının sosyal medya bağımlılıklarını yordayıcı rolünün incelenmesi. Yüksek Lisans Tezi, Çağ Üniversitesi Sosyal Bilimler Enstitüsü.

Atmaca, H. (1997). Boş zaman-kütüphane bağlamında psikolojik ve sosyolojik açılardan birey. Türk Kütüphaneciliği, 11(4), 326-336.

Awada, G. (2016). Effect of WhatsApp on critique writing proficiency and perceptions toward learning. Cogent Education, 3(1), 1-25. https://dx.doi.org/10.1080/2331186X.2016.1264173

Bai, Y., Lin, C. C., Lin, C. Y., Chen, J. Y., Chue, C. M., \& Chou, P. (2004). Survey of stress reactions among health care workers involved with the SARS outbreak. Psychiatric Services, 55(9), 1055-1057. https://dx.doi.org/10.1176/appi.ps.55.9.1055

Banks, M. R., Willoughby, L. M., \& Banks, W. A. (2008). Animal-assisted therapy and loneliness in nursing homes: use of robotic versus living dogs. Journal of the American Medical Directors Association, 9(3), 173-177. https://dx.doi.org/10.1016/j.jamda.2007.11.007

Beer, A. R. (1990). Environmental planning for site development. Londra: E \& F. N. Spon.

Beranuy, M., Oberst, U., Carbonell, X., \& Chamarro, A. (2009). Problematic Internet and mobile phone use and clinical symptoms in college students: The role of emotional intelligence. Computers in Human Behavior, 25(5), 1182-1187. https://dx.doi.org/10.1016/j.chb.2009.03.001

Berget, B., Ekeberg, Ø., \& Braastad, B. O. (2008). Animal-assisted therapy with farm animals for persons with psychiatric disorders: effects on self-efficacy, coping ability and quality of life, a randomized controlled trial. Clinical Practice and Epidemiology in Mental Health, 4(1), 1-7. 
Berget, B., Ekeberg, Ø., Pedersen, I., \& Braastad, B. O. (2011). Animal-assisted therapy with farm animals for persons with psychiatric disorders: Effects on anxiety and depression, a randomized controlled trial. Occupational Therapy in Mental Health, 27(1), 50-64.

Bian, M., \& Leung, L. (2015). Linking loneliness, shyness, smartphone addiction symptoms, and patterns of smartphone use to social capital. Social Science Computer Review, 33(1), 61-79. https://dx.doi.org/10.1177/0894439314528779

Buhr, K., \& Dugas, M. J. (2002). The intolerance of uncertainty scale: Psychometric properties of the English version. Behaviour Research and Therapy, 40(8), 931-945. https://dx.doi.org/10.1016/S0005-7967(01)00092-4

Buhr, K., \& Dugas, M. J. (2006). Investigating the construct validity of intolerance of uncertainty and its unique relationship with worry. Journal of Anxiety Disorders, 20(2), 222-236. https://dx.doi.org/10.1016/j.janxdis.2004.12.004

Büyükcebeci, A., \& Yılmaz, H. (2019, Nisan). Evcil hayvan beslemeye karşı yaklaşımının bazı kişilik özellikleri açısından incelenmesi. 3. Uluslararası Avrasya Sosyal Bilimler Kongresi'nde sunulan bildiri, Muğla.

Caplan, S. E. (2002). Problematic Internet use and psychosocial well-being: development of a theory-based cognitive-behavioral measurement instrument. Computers in Human Behavior, 18(5), 553-575. https://dx.doi.org/10.1016/S0747-5632(02)00004-3

Carleton, R. N., Norton, M. P. J., \& Asmundson, G. J. (2007). Fearing the unknown: A short version of the Intolerance of Uncertainty Scale. Journal of Anxiety Disorders, 21(1), 105117. https://dx.doi.org/10.1016/j.janxdis.2006.03.014

Chong, M. Y., Wang, W. C., Hsieh, W. C., Lee, C. Y., Chiu, N. M., Yeh, W. C., Huang, T. L., Wen, J. K., \& Chen, C. L. (2004). Psychological impact of severe acute respiratory syndrome on health workers in a tertiary hospital. The British Journal of Psychiatry, 185(2), 127-133. https://dx.doi.org/10.1192/bjp.185.2.127

Cohen, R. E., \& Anderson, D. L. (1986). Botulism: emotional impact on patient and family. Journal of Psychosomatic Research, 30(3), 321-326. https://dx.doi.org/10.1016/0022-3999(86)90009-7

Cole, D.N. \& Hall, T.E. (2010). Experiencing the restorative components of wilderness environments: Does congestion interfere and does length of exposure matter. Environment and Behavior, 42(6), 806-823. https://dx.doi.org/10.1177/0013916509347248

Cooper-Marcus, C. \& Barnes, M. (1999). Healing gardens: therapeutic benefits and design recommendations. New York: John Wiley \& Sons.

Çakır, B., Karaarslan, G., Şahin, E. \& Ertepınar, H. (2015). Doğayla ilişkili olma ölçeğinin Türkçe'ye uyarlanması. İlköğretim Online, 14(4), 1370-1383.

Çorapçıŏlu, A., Yargıç, İ., Geyran, P., \& Kocabaşoğlu, N. (2006). Olayların etkisi ölçeği (IES-R) Türkçe versiyonunun geçerlilik ve güvenilirliği. Yeni Symposium, 44(1), 14-22.

de Medeiros Carvalho, P. M., Moreno Moreira, M., Arcanjo de Oliveira, M. N., Macedo Landim, J. M., \& Rolim Neto, M. L. (2020). The psychiatric impact of the novel coronavirus outbreak. Psychiatry Research, 286, 1-2. https://doi.org/10.1016/j.psychres.2020.112902

Duan, L., \& Zhu, G. (2020). Psychological interventions for people affected by the Covid-19 epidemic. The Lancet Psychiatry, 7(4), 300-302. https://dx.doi.org/10.1016/S22150366(20)30073-0 
Eastwood, J. D., Fahlman, S. A., Mercer-Lynn, K. B. \& Flora, D. B. (2013). Development and validation of the multidimensional state boredom scale. Assessment, 20(1), 68-85. https://dx.doi.org/10.1177/1073191111421303

Erkul, R. E. (2009). Sosyal medya araçlarının (Web 2.0) kamu hizmetleri ve uygulamalarında kullanılabilirliği. Türkiye Bilişim Derneği Bilişsim Dergisi, 11(6), 96-101.

Ertem, F. (2006). Cep telefonu kullanımının insan ilişkilerine etkisi [Yayımlanmamış Yüksek Lisans Tezi]. Haliç Üniversitesi Sosyal Bilimler Enstitüsü.

Fergus, T. A., \& Wu, K. D. (2011). Searching for specificity between cognitive vulnerabilities andmood and anxiety symptoms. Journal of Psychopathology and Behavioral Assessment, 33(4), 446-458. https://dx.doi.org/10.1007/s10862-011-9245-6

Garrity T. F., Stallones L., Marx M. B. \& Johnson T. P. (1989). Pet ownership and attachment as supportive factors in the health of the elderly. Anthrozoös, 3(1), 35-44. https://dx.doi.org/10.2752/089279390787057829

Gómez-Salgado, J., Andrés-Villas, M., Domínguez-Salas, S., Díaz-Milanés, D., \& Ruiz-Frutos, C. (2020). Related health factors of psychological distress during the COVID-19 Pandemic in Spain. International Journal of Environmental Research and Public Health, 17(11), 39-47. https://dx.doi.org/10.3390/ijerph17113947

Guthrie, M. F., Marshall, P. H., Hendrick, S. S., Hendrick, C., \& Logue, E. (2018). Human love styles and attitudes toward pets. Anthrozoös, 31(1), 41-60. https://dx.doi.org/10.1080/08927936.2018.1406200

Harrison, S. (2005). Y@Our library: What do millennials want? Access, 11(2), 21-23. https://doi.org/10.1016/j.chb.2019.09.030

Hartig, T., Johansson, G. \& Kylin, C. (2003). Residence in the social ecology of stress and restoration. Journal of Social Issues, 59(3), 611-636. https://dx.doi.org/10.1111/15404560.00080

Hawryluck, L., Gold, W. L., Robinson, S., Pogorski, S., Galea, S., \& Styra, R. (2004). SARS control and psychological effects of quarantine, Toronto, Canada. Emerging Infectious Diseases, 10(7), 1206-1212.

Himsworth, C. G., \& Rock, M. (2013). Pet ownership, other domestic relationships, and satisfaction with life among seniors: Results from a Canadian national survey. Anthrozoös, 26(2),295-305.

https://dx.doi.org/10.2752/175303713X13636846944448

Horowitz, M., Wilner, N., \& Alvarez, W. (1979). Impact of Event Scale: A measure of subjective stress. Psychosomatic Medicine, 41(3), 209-218.

Iso-ahola, S. \& Weissinger, E. (1990). Perceptions of boredom in leisure: conceptualization, reliability and validity of the leisure boredom scale. Journal of Leisure Research, 22, 1-17. https://dx.doi.org/10.1080/00222216.1990.11969811

Kalecik, S. (2016). Emotion regulation, self-control, novelty Seeking, Depression and Social Anxiety Symptoms in Relation to Problematic Internet and Smartphone Use [Yayımlanmamış yüksek lisans tezi]. Bahçeşehir Üniversitesi Sosyal Bilimler Enstitüsü.

Kaplan, A. M., \& Haenlein, M. (2009). Users of the world, unite! The challenges and opportunities $\begin{array}{lll}\text { of social } & \text { Media. Business }\end{array}$ https://dx.doi.org/10.1016/j.bushor.2009.09.003 
Khawaja, N. G., \& McMahon, J. (2011). The relationship of meta-worry and intolerance of uncertainty with pathological worry, anxiety, and depression. Behaviour Change, 28(4), 165-180. https://dx.doi.org/10.1145/1180875.1180901

Liem, A., Wang, C., Wariyanti, Y., Latkin, C. A., \& Hall, B. J. (2020). The neglected health of international migrant workers in the COVID-19 epidemic. The Lancet Psychiatry, 7(4), 1. https://dx.doi.org/10.1016/S2215-0366(20)30076-6

Lin, M. P., Ko, H. C., \& Wu, J. Y. W. (2011). Prevalence and psychosocial risk factors associated with Internet addiction in a nationally representative sample of college students in Taiwan. Cyberpsychology, Behavior, and Social Networking, 14(12), 741-746. https://dx.doi.org/10.1089/cyber.2010.0574

Liu, N., Zhang, F., Wei, C., Jia, Y., Shang, Z., Sun, L., Wu, L., Sun, Z., Zhou, Y., \& Liu, W. (2020). Prevalence and predictors of PTSS during COVID-19 outbreak in China hardest-hit areas: Gender differences matter. Psychiatry Research 287, 1-7. https://dx.doi.org/10.1016/j.psychres.2020.112921

Liu, X., Kakade, M., Fuller, C. J., Fan, B., Fang, Y., Kong, J., Guan, Z., \& Wu, P. (2012). Depression after exposure to stressful events: lessons learned from the severe acute respiratory syndrome epidemic. Comprehensive Psychiatry, 53(1), 15-23. https://dx.doi.org/10.1016/j.comppsych.2011.02.003

Mahoney, A. E., \& McEvoy, P. M. (2012). Trait versus situation-specific intolerance of uncertainty in a clinical sample with anxiety and depressive disorders. Cognitive Behaviour Therapy, 4l(1), 26-39. https://dx.doi.org/10.1080/16506073.2011.622131

Marjanovic, Z., Greenglass, E. R., \& Coffey, S. (2007). The relevance of psychosocial variables and working conditions in predicting nurses' coping strategies during the SARS crisis: an online questionnaire survey. International Journal of Nursing Studies, 44(6), 991-998. https://dx.doi.org/10.1016/j.ijnurstu.2006.02.012

Maunder, R., Hunter, J., Vincent, L., Bennett, J., Peladeau, N., Leszcz, M., Sadavoy, J., Verhaeghe, L. M., Steinberg, R., \& Mazzulli, T. (2003). The immediate psychological and occupational impact of the 2003 SARS outbreak in a teaching hospital. Cmaj, 168(10), $1245-1251$.

Mikulas, W. L., \& Vodanovich, S. (1993). The essence of boredom. The Psychological Record, 43(1), 3-12.

Mihashi, M., Otsubo, Y., Yinjuan, X., Nagatomi, K., Hoshiko, M., \& Ishitake, T. (2009). Predictive factors of psychological disorder development during recovery following SARS outbreak. Health Psychology, 28(1), 91-100. https://dx.doi.org/10.1037/a0013674

Nickell, L. A., Crighton, E. J., Tracy, C. S., Al-Enazy, H., Bolaji, Y., Hanjrah, S., Hussain, A., Makhlouf, S., \& Upshur, R. E. (2004). Psychosocial effects of SARS on hospital staff: survey of a large tertiary care institution. Cmaj, 170(5), 793-798. https://dx.doi.org/10.1503/cmaj.1031077

Norr, A. M., Oglesby, M. E., Capron, D. W., Raines, A. M., Korte, K. J., \& Schmidt, N. B. (2013). Evaluating the unique contribution of intolerance of uncertainty relative to other cognitive vulnerability factors in anxiety psychopathology. Journal of Affective Disorders, 151(1), 136-142. https://dx.doi.org/10.1016/j.jad.2013.05.063

Özdemir, A. \& Kıray Vural, B. (2015). Yaşlıların doğa/bahçe algıları üzerine araştırma: Denizli örneği. İnönü Üniversitesi Sanat ve Tasarım Dergisi, 11(5), 65-77. 
Phillips, A., (1993). On kissing, tickling, and being bored: psychoanalytic essays on the unexamined life. Cambridge: Harvard University Press.

Poole, K., Hood, K., Davis, B. D., Monypenny, I. J., Sweetland, H., Webster, D. J. T., Lyons, K., \& Mansel, R. E. (1999). Psychological distress associated with waiting for results of diagnostic investigations for breast disease. The Breast, 8(6), 334-338. https://dx.doi.org/10.1054/brst.1999.0085

Roberts, J. A., Pullig, C., \& Manolis, C. (2015). I need my smartphone: A hierarchical model of personality and cell-phone addiction. Personality and Individual Differences, 79, 13-19. https://dx.doi.org/10.1016/j.paid.2015.01.049

Salkaya, A.D. (2020). Yeni medyada çocuk içerik üreticileri: yaşam biçimi sunumu ve toplumsal cinsiyet rolleri üzerinden youtube çocuk kanalları [Yayımlanmış Yüksek Lisans Tezi]. İstanbul Üniversitesi Sosyal Bilimler Enstitüsü.

Sansone, C., Weir, C., Harpster, L., \& Morgan, C. (1992). Once a boring task always a boring task? Interest as a self-regulatory mechanism. Journal of Personality and Social Psychology, 63(3), 379-390. https://dx.doi.org/10.1037/0022-3514.63.3.379

Sarıçam, H., Erguvan, F. M., Akın, A., \& Akça, M. Ş. (2014). Belirsizliğe tahammülsüzlük ölçeği (BTÖ-12) Türkçe formu: Geçerlik ve güvenirlik çalışması. Route Educational and Social Science Journal, 1(3), 148-157.

Satici, B., Saricali, M., Satici, S. A., \& Griffiths, M. D. (2020). Intolerance of uncertainty and mental wellbeing: serial mediation by rumination and fear of COVID-19. International Journal of Mental Health and Addiction, 15, 1-12. https://dx.doi.org/10.1007/s11469-02000305-0

Sherman, S.A., Mc Cuskey Shepley, M. \& Vami, J.W. (2005). Children's environments and health related quality of life: evidence informing pediatric healthcare environmental design. Children Youth and Environments, 15(1), 186-223.

Sh Ho, C., Yi Chee, C., \& Cm Ho, R. (2020). Mental health strategies to combat the psychologicalimpact of Covid-19 beyond paranoia and panic. Ann Acad Med Singapore, 49(1), 1-3.

Smith, J. L., Wagaman, J., \& Handley, I. M. (2009). Keeping it dull or making it fun: Task variation as a function of promotion versus prevention focus. Motivation and Emotion, $33(2), 150-160$.

Soylu, Y., \& Siyez, D. (2014). Boş zaman can sıkıntısı ölçeği’nin Türkçe’ye uyarlanması. Ege Eğitim Dergisi, 15(1), 80-95.

Sprang, G., \& Silman, M. (2013). Posttraumatic stress disorder in parents and youth after healthrelated disasters. Disaster Dedicine and Public Health Preparedness, 7(1), 105-110.

Stanley Budner, N. Y. (1962). Intolerance of ambiguity as a personality variable 1. Journal of Personality, 30(1), 29-50. https://dx.doi.org/10.1111/j.1467-6494.1962.tb02303.x

Suna A. H. (2019). Türkiye'de yaşayan evcil hayvan sahiplerinin bütüncül psikoterapi perspektifinden analizi. Türkiye Bütüncül Psikoterapi Dergisi, 2(3), 131-153.

Şakiroğlu, M. (2019). The effect of self control and emotion regulation difficulties on the problematic smart phone use of young people. Uluslararası Eğitim Programları ve Öğretim Çalışmaları Dergisi, 9(2), 301-308. https://dx.doi.org/10.31704/ijocis.2019.013 
Tatlılığlu, K. (2015). Üniversite öğrencilerinin aylık gelir ve harcama düzeyi ile psikolojik iyi oluşları arasındaki ilişkinin incelenmesi (Bingöl Üniversitesi örneği). Electronic Journal of Social Sciences, 14(55), 1-15.

Tavares Lima, C. K. T., de Medeiros Carvalho, P. M., Tavares Lima, I. D. A. S., de Oliveira Nunes, J. V. A. Saraiva, J. S., de Souza, R. I., ... \& Neto, M. L. R. (2020). The emotional impact of Coronavirus 2019-nCoV (new Coronavirus disease). Psychiatry research, 287, 1-2. https://dx.doi.org/10.1016/j.psychres.2020.112915

Taylor, M. R., Agho, K. E., Stevens, G. J., \& Raphael, B. (2008). Factors influencing psychological distress during a disease epidemic: data from Australia's first outbreak of equine influenza. BMC Public Health, 8(1), 1-13. https://doi.org/10.1186/1471-2458-8-347

T.C. Sağlık Bakanlığı (2020, Haziran 15). https://covid19bilgi.saglik.gov.tr/tr/haberler/turkiyedeki-gunluk-covid-19-vaka-sayilari.html

Tezcan, M. (1982). Sosyolojik açıdan boş zamanların değerlendirilmesi. Ankara Üniversitesi Eğitim Bilimleri Fakültesi Yayınları, 11(1), 165-179.

Thompson, D. R., Lopez, V., Lee, D., \& Twinn, S. (2004). SARS-a perspective from a school of nursing in Hong Kong. Journal of Clinical Nursing, 13(2), 131-135. https://dx.doi.org/10.1046/j.1365-2702.2003.00884.x

TÜİK (2016). http://tuik.gov.tr/PreHaberBultenleri.do?id=21779

TÜİK (2017).

http://www.tuik.gov.tr/PreHaberBultenleri.do;jsessionid=ZksNZYpByB7Y2NRT0r6T6Gf v0TngGDh0Q31WcDQ2FvhYL2sSn8C!86854652?id=24862.

Ulrich, R. S. (1992). Influences of passive experiences with plants on individual well-being and health. The Role of Horticulture in Human Well-being and Social Development, 4(1), 93105.

Üçer, N. (2016). Kullanımlar ve doyumlar yaklaşımı bağlamında gençlerin sosyal media kullanımına yönelik niteliksel bir araştırma. Global Media Journal: Turkish Edition, 6(12), $1-27$.

Üstün, Ç., \& Özçiftçi, S. (2020) Covid-19 pandemisinin sosyal yaşam ve etik düzlem üzerine etkileri: bir değerlendirme çalışması. Anadolu Kliniği Tıp Bilimleri Dergisi; 25(1), 142-

153. https://dx.doi.org/10.21673/anadoluklin.721864

Van Tilburg, W. A. P. \& Igou, E. R. (2011). On boredom and social identity: a pragmatic meaning regulation approach. Personality and Social Psychology Bulletin, 37(12), 1679-1691. https://dx.doi.org/10.1177/0146167211418530

Van Tilburg, W. A. P., Igou, E. R., \& Sedikides, C. (2013). In search of meaningfulness: Nostalgia as an Antidote to Boredom. Emotion, 13(3), 450-461.

Wang, C., Pan, R., Wan, X., Tan, Y., Xu, L., Ho, C. S., \& Ho, R. C. (2020). Immediate psychological responses and associated factors during the initial stage of the 2019 coronavirus disease (COVID-19) epidemic among the general population in China. International Journal of Environmental Research and Public Health, 17(5), 17-29. https://doi.org/10.3390/ijerph17051729

Weiss, D. S., \& Marmar, C. R. (1997). The impact of event scale—revised. In J. P. Wilson, \& T. M. Keane (Eds.), Assessing psychological trauma and PTSD: A handbook for practitioners. New York: Guilford Press. 
Whang, L. S. M., Lee, S., \& Chang, G. (2003). Internet over-users' psychological profiles: a behavior sampling analysis on internet addiction. Cyberpsychology \& Behavior, 6(2), 143150. https://dx.doi.org/10.1089/109493103321640338

Whitehouse, S., Vami, J.W., Seid, M., Cooper- Marcus, C., Ensberg, M.J., Jacobs, J.R. \& Mehlenbeck, R.S (2001). Evaluating a children's hospital garden environment: utilization and consumer satisfaction. Journal of Environmental Psychology, 21, 301-314. https://dx.doi.org/10.1006/jevp.2001.0224

WHO (2020a, 15 Haziran). https://www.who.int/csr/don/05-january-2020-pneumonia-ofunkown-cause-china/en/

WHO (2020b, 15 Haziran). http://www.euro.who.int/en/healthtopics/healthemergencies/coronavirus-covid-19/covid-19-latest-updates

WHO (2020c, $02 \quad$ Temmuz). http://experience.arcgis.com/experience/685d0ace 521648f8a5beeeee1b9125cd

Wu, K. K., Chan, S. K., \& Ma, T. M. (2005). Posttraumatic stress, anxiety, and depression in survivors of severe acute respiratory syndrome (SARS). Journal of Traumatic Stress: Official Publication of The International Society for Traumatic Stress Studies, 18(1), 3942. https://dx.doi.org/10.1002/jts.20004

Wu, P., Fang, Y., Guan, Z., Fan, B., Kong, J., Yao, Z., Liu, X., Fuller, C. J., Susser, E., Lu, J., \& Hoven, C. W. (2009). The psychological impact of the SARS epidemic on hospital employees in China: exposure, risk perception, and altruistic acceptance of risk. The Canadian Journal of Psychiatry, 54(5), 302-311. https://dx.doi.org/10.1177/070674370905400504

Xiang, Y. T., Yang, Y., Li, W., Zhang, L., Zhang, Q., Cheung, T., \& Ng, C. H. (2020). Timely mental health care for the 2019 novel coronavirus outbreak is urgently needed. The Lancet Psychiatry, 7(3), 228-229. https://dx.doi.org/10.1016/S2215-0366(20)30073-0

Yen, J. Y., Ko, C. H., Yen, C. F., Wu, H. Y., \& Yang, M. J. (2007). The comorbid psychiatric symptoms of Internet addiction: attention deficit and hyperactivity disorder (ADHD), depression, social phobia, and hostility. Journal of Adolescent Health, 41(1), 93-98. https://dx.doi.org/10.1016/j.jadohealth.2007.02.002

Yeşilkayalı, E., \& Ofluoğlu, A. (2018). Aile değerlendirmelerinde bir alt sistem olarak evcil hayvan: genel bir çerçeve. Turkish Studies, 13(26), 1-17. https://dx.doi.org/10.7827/TurkishStudies.14501 